University of Texas Rio Grande Valley

ScholarWorks @ UTRGV

$11-1-2021$

\title{
Review: ¡Viva George!: Celebrating Washington's Birthday at the US-Mexico Border, by Elaine A. Peña
}

George T. Diaz

The University of Texas Rio Grande Valley, george.diaz@utrgv.edu

Follow this and additional works at: https://scholarworks.utrgv.edu/hist_fac

Part of the History Commons

\section{Recommended Citation}

George T. Díaz; Review: ¡Viva George!: Celebrating Washington’s Birthday at the US-Mexico Border, by Elaine A. Peña. Pacific Historical Review 1 November 2021; 90 (4): 552-553. doi: https://doi.org/10.1525/ phr.2021.90.4.552

This Article is brought to you for free and open access by the College of Liberal Arts at ScholarWorks @ UTRGV. It has been accepted for inclusion in History Faculty Publications and Presentations by an authorized administrator of ScholarWorks@ UTRGV. For more information, please contact justin.white@utrgv.edu, william.flores01@utrgv.edu. 
providing an analysis of how activists went up against long standing religious institutions to fight for community programs and better housing. Hinojosa juxtaposes traditional primary sources such as manifestos alongside oral histories to provide vivid details regarding the people-led occupations that are accompanied by over thirty images.

The body chapters depict how Latina/os challenged power. Chapter One explores the five-day occupation of the McCormick Theological Seminary by the YLO who sought funding for a legal office, a health clinic, and low-income housing in Chicago's Lincoln Park neighborhood. The second chapter moves to Christmas Eve 1969 in Los Angeles by focusing on how Chicana/os from Católicos Por La Raza disrupted mass at St. Basil's Church to advocate for the church to respond to the social needs of the community. Chapter Three shifts back to the Young Lords in New York in 1970 when they occupied the First Spanish United Methodist Church in East Harlem for two weeks while providing social services. Chapter Four returns to the Chicana/o movement by centering how members of the Mexican American Youth Organization occupied Juan Marcos Presbyterian Church in Houston's northside barrio in 1970 as they debated the role the church could play in community activism.

Apostles of Change is a welcomed contribution to the literature on Latina/o political movements for its utilization of religion and urban history as frameworks of analysis. Scholars of social movements, urban history, and religion will find Hinojosa's study imperative for understanding how grassroots activists challenged gentrification, discrimination, and power that connects the stories in the book to present obstacles facing Latina/os.

University of Pittsburgh

Eddie Bonilla

iViva George!: Celebrating Washington's Birthday at the US-Mexico Border. By Elaine A. Peña. (Austin, University of Texas Press, 2020. 216 pp.)

Elaine A. Peña's iViva George! offers an in-depth "anthropological history" of the ways a binational community's celebration of George Washington's birthday bridges national and cultural divides across the U.S.-Mexico border (p. 6). For over one hundred years, Laredo, Texas-a medium-sized community along the Rio Grande-has celebrated the birthday of the first president of the United States. Rather than fetishize the celebration as a border eccentricity, the book considers how Mexican Americans embraced and co-opted 
the festivity to cultivate a unique identity. Moreover, the book considers how local and regional business interests contended with U.S. and Mexican national policies in shaping border enforcement.

Identity takes center stage in the book. George Washington's birthday celebration came to the border in late nineteenth century when Anglo and Euro American newcomers sought to impose a U.S. identity on a predominately ethnic Mexican town. Celebrants belonging to the fraternal organization "Improved Order of the Red Men" (IORM) dressed in red face and engaged in mock battles as part of the events. Peña utilizes Philip Deloria's concept of "playing Indian" to contextualize white American men's practice of selectively embracing indigenous accoutrement to assert belonging (2I). Still, in Laredo, Mexican American elites wielded such sway that the IORM added Montezuma and Yaqui names to their rolls providing a Pan American element to the festivities.

By the 1960 s, the celebration had grown beyond re-enactments of the Boston Tea Party on the Rio Grande to an elaborate and lucrative celebration with binational government support. Performers from both sides of the border marched in the local parade where U.S. and Mexican flags flew side by side. Moreover, crowds thronged to spend their money in both the United States and Mexico. Such easy flow of pesos and dollars prompted the relaxing of crossing restrictions through the practice of "paso libre," a four-day visa waiver allowing tens of thousands to pass freely (p. 72). Beginning in 1957, local and regional government succeeded in making the celebration of Washington's Birthday an "open house" for the border (p. 72). The ritual embrace of children from Mexico and the United States, each dressed in expensive costumes indicating their respective nations in an abrazo along the international bridge, did much to allay state fears of lax border security, but could not keep the four-day visa waiver for the celebration from coming to an end in 1976.

Informative and concise, iViva George! should appeal to students in both graduate and undergraduate courses in border studies as well as American and Mexican American studies classes. The book is composed from archival sources in both the United States and Mexico, making it a model of transnational research. Moreover, Peña's years of field work in Los dos Laredos as an observer in the celebration give the book a street-level view that makes the book engaging. 